http://jmscr.igmpublication.org/home/ ISSN (e)-2347-176x ISSN (p) 2455-0450

crossref DOI: https://dx.doi.org/10.18535/jmscr/v8i9.41

\title{
Breast Self-examination: Knowledge, Attitude and Practice among Female Nursing Undergraduate Students in the Northern Border University, KSA
}

\author{
Authors \\ Dr Heba A. Osman ${ }^{1}$, Ms. Deepa Jothirajan ${ }^{2 *}$, Ms. Maurine T. Conde ${ }^{3}$, \\ Ms. Chithra Thanganadar ${ }^{4}$, Ms. Lylathul Nisha Rasheed ${ }^{5}$, Ms. Reshmi RS ${ }^{6}$ \\ ${ }^{1}$ Assistant Professor of Obstetric and Gynaecological Nursing, Faculty of Nursing, Northern Border \\ University, KSA \\ 2,3,4,5,6 Lecturer of Obstetric and Gynaecological Nursing, Faculty of Nursing, Northern Border University, \\ KSA \\ *Corresponding Author \\ Ms. Deepa Jothirajan
}

\begin{abstract}
Breast self-examination (BSE) is one of the interventions to detect the breast cancer (BC) earlier. Nowadays, BSE didn't known by the many adolescent and young women, so that it is needed to do promotive effort to increase their knowledge about BSE. This was a cross sectional study of 100 female nursing students that were selected by cluster sampling technique, data was collected using selfadministered questionnaires and analysis done using SPSS Version 19.The level of awareness of breast cancer and BSE was high among the respondents; 98\% of surveyed girls had heard about BC, but only few had limited knowledge The breast feeding and breast self-examination reported as a methods of prevention breast cancer. Breast lump was a well-known symptom of breast cancer. 57\% of the respondents knew the correct time BSE should be done, minority of the participants had a good knowledge of BSE, the practice of $B S E$ was poor, only $34 \%$ of them carried it out monthly; more than half of the respondents $52 \%$ said they will seek help immediately if they observed breast lump.
\end{abstract}

Keywords: Breast cancer, Breast self-examination, Undergraduate Nursing Students, Arar.

\section{Introduction}

Breast cancer is the most common cancer in women globally and has become an issue of public health importance. According to the International Agency for Research on Cancer (IARC) GLOBOCAN 2012, 1.7 million women were diagnosed with breast cancer in $2012 .{ }^{[1]}$ It was responsible for approximately half a million deaths in women worldwide in 2012, affecting both developed and developing countries. Breast cancer is one of the health problems in KSA and the World and it has been identified as a major impact on health of women worldwide and the Kingdom of Saudi Arabia (KSA) is no exception Breast self-examination (BSE); it is still could be a life-saving technique through inspiring and empowering women to take better control over their body/breast and health.

To reduce the burden of breast cancer in KSA, it is necessary to first determine the level of knowledge and practice relating to breast selfexamination as a breast cancer prevention strategy especially among our teaming youths who at this stage of life can continue this practice to 
adulthood. Therefore this study was aimed to identify the level of knowledge and practice of breast self-examination among female undergraduates in Arar, KSA.

\section{Statement of the Problem}

A study to assess the knowledge, attitude and practice among Female Nursing Undergraduate Students in the Northern Border University, Arar KSA.

\section{Objectives}

To find out the knowledge and attitude of breast self-examination and to describe the extent of practice of breast self-examination among them.

\section{Research design and approach}

Research approach selected for this study was non experimental approach.

Descriptive- correlational design.

\section{Setting of the study}

The study was conducted in Northern Border University, KSA

\section{Population}

The populations of this study were all female nursing students Northern Border University, Arar KSA

\section{Sampling Technique}

Cluster sampling technique was used for this study

\section{Sample size}

100 participants were from second, third and fourth year Nursing Students, Northern Border University, KSA.

\section{Tools used}

\section{1) A Self-Administered Questionnaire:}

It has five sections. Part A. part B, part C, part D and part E.

Part A: Socio-demographic characteristic used in this study were age, marital status, gravidity, previous knowledge on breast self-examination, family history for breast cancer, father education and mother education.

Part B: Menstrual, medical, and family history age at menarche, regular cycle, have menstrual problem, have chronic disease, problems is related to menses etc..,

Part C: Sources of information about breast cancer among participants.

Part D: Barriers for practicing breast selfexamination among participants.

Part E: Methods for prevention or decrease risk of breast cancer among participants.

\section{2) Breast Self - Examination Knowledge Checklist}

It was used to assess the participants' knowledge regarding BSE. It consists of 20 statements which, include meaning of BSE, purposes of doing BSE, ideal age for practicing, proper time for performing BSE, the frequency of practicing BSE...etc. For knowledge items, categorical responses (true/false/don't know) were applied.

\section{Scoring System}

Each question had a group of answer points, each correct response had two grades, one grade for don't know while, incorrect response had zero. The total score level for these items were between 0 and 40 when the total participants' score level for knowledge was $60 \%$ and above is considered satisfactory knowledge, while below $60 \%$ was considered unsatisfactory knowledge.

\section{3) Breast Self- Examination Attitudes} Assessment Sheet:

It was prepared to assess and measure the participants' attitudes towards BSE. It consists of 13 statements. All statements were scored on a scale from (0-3), whereas, participants' responses with strongly agree scored (3), agree scored (2), disagree scored (1) and strongly disagree scored (Zero).Whereas, the total attitude score was 39 scores. The total score was divided into two categories as the following: (Scores from (20 -39) referred to positive attitudes while Scores from (0<20) referred to negative attitudes.

\section{4) Breast Self - Examination Performance} Checklist

This tool was developed by the researchers to assess participants' performance of BSE through observation. It consists of seven consecutive steps. All items were made using done or not done 
Results

Table 1: Socio-demographic profile of the participants

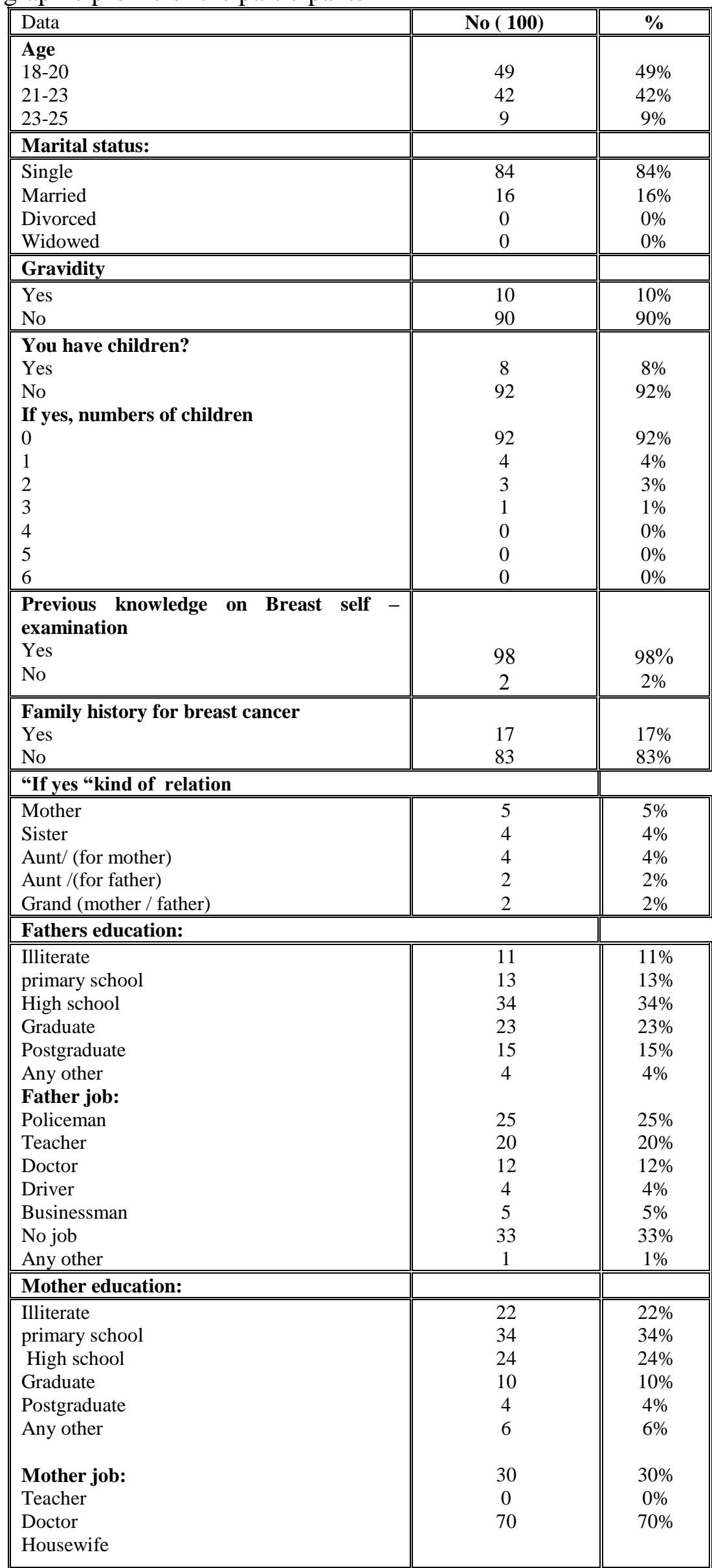


Table 2: Menstrual, medical, and family history of the women participants

\begin{tabular}{||l||c|c|}
\hline \multicolumn{1}{|c||}{} & No (100) & \% \\
\hline \hline Age at menarche: & 94 & $94 \%$ \\
\hline$<20$ & 6 & $6 \%$ \\
\hline $20+$ & & \\
\hline Regular cycle & 65 & $65 \%$ \\
\hline \hline Yes & & $35 \%$ \\
\hline No & 16 & $16 \%$ \\
\hline Have menstrual problems: & 84 & $84 \%$ \\
\hline Yes & & \\
\hline No & 4 & $4 \%$ \\
\hline Problems: & 6 & $6 \%$ \\
\hline Mastalgia & 0 & $0 \%$ \\
\hline Nipple secretions & 6 & $6 \%$ \\
\hline Nipple color change & & \\
\hline Engorgement & 9 & $9 \%$ \\
\hline Problems is related to menses & 7 & $7 \%$ \\
\hline Yes & & \\
\hline No & 5 & $5 \%$ \\
\hline Sought medical advice & 4 & $4 \%$ \\
\hline Yes & & \\
\hline No & & \\
\hline
\end{tabular}

Table 3: Sources of information about breast cancer among the study participants

\begin{tabular}{|l||c|c|}
\hline Sources of information: & No & $\%$ \\
\hline \hline Newspaper & 2 & $2 \%$ \\
\hline \hline Magazine & 2 & $2 \%$ \\
\hline \hline Radio & 15 & $15 \%$ \\
\hline \hline Internet & 4 & $4 \%$ \\
\hline \hline Health personnel & 34 & $34 \%$ \\
\hline \hline Family member & 28 & $28 \%$ \\
\hline \hline Teacher & 10 & $10 \%$ \\
\hline \hline Friends & 5 & $5 \%$ \\
\hline \hline
\end{tabular}

Table 4: Barriers for practicing breast self -examination among the study participants

\begin{tabular}{|l||c||c|}
\hline \multicolumn{1}{|l||}{ Items } & No & $\%$ \\
\hline \hline Yes & 30 & $30 \%$ \\
No & 70 & $70 \%$ \\
\hline \hline Barriers for practicing breast self -examination in case of yes \\
\hline \hline Lack of knowledge & 5 & $16.7 \%$ \\
\hline \hline Dislike to touch breast & 7 & $23.3 \%$ \\
\hline \hline Fear/worry to find a lump & 6 & $20 \%$ \\
\hline \hline No time & 7 & $23.3 \%$ \\
\hline \hline Forgetfulness & 4 & $13.3 \%$ \\
\hline \hline Culture and health beliefs & $0 \%$ & $0 \%$ \\
\hline \hline In availability of specialized center & $0 \%$ & $0 \%$ \\
\hline \hline Embarrassment & $0 \%$ & $0 \%$ \\
\hline Lack of privacy & $0 \%$ & $0 \%$ \\
\hline \hline Lack of confidence & $0 \%$ & $0 \%$ \\
\hline \hline Fear of finding some abnormality & $1 \%$ & $3.3 \%$ \\
\hline \hline Not at risk hence not required to do & $0 \%$ & $0 \%$ \\
\hline \hline
\end{tabular}


Table 5: The participants' knowledge about breast cancer and breast self-examination (BSE)

\begin{tabular}{|l|}
\hline Satisfactory Knowledge of: \\
\hline $\begin{array}{l}\text { Methods for prevention or decrease risk of } \\
\text { breast cancer }\end{array}$ \\
\hline Breast self-examination \\
\hline \hline Breastfeeding \\
\hline \hline Not using the contraceptive for a long time \\
\hline \hline Healthy food \\
\hline \hline Don't known
\end{tabular}

\begin{tabular}{|c|c|}
\hline No. & $\%$ \\
\hline $\begin{array}{ll}16 \\
6\end{array}$ & $16 \%$ \\
\hline $\begin{array}{c}84 \\
\end{array}$ & $84 \%$ \\
\hline $\bar{~} \overline{0}$ & $0 \%$ \\
\hline 0 & $0 \%$ \\
\hline 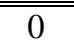 & $0 \%$ \\
\hline
\end{tabular}

\begin{tabular}{|c|c|c|c|}
\hline Satisfactory of knowledge: & Incorrect & Don't know & Correct \\
\hline Knowledge questions & $\%$ & $\%$ & $\%$ \\
\hline The meaning of BSE & 26 & 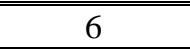 & 68 \\
\hline The main purpose of doing BSE & 36 & 9 & 55 \\
\hline The ideal age in years when the women should begin practicing BSE & 34 & 9 & 57 \\
\hline BSE must be done between day 7 until day 10 after menses & 27 & 17 & 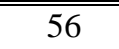 \\
\hline BSE should be done during this period because breast becomes soft & 18 & 26 & 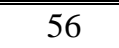 \\
\hline BSE should be done every 2 months & 47 & 16 & 37 \\
\hline BSE done to detect any abnormality & 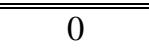 & 48 & 52 \\
\hline BSE should be done in front of the mirror & 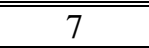 & 18 & 75 \\
\hline Undress until the waist when doing the BSE & 11 & 24 & 65 \\
\hline $\begin{array}{l}\text { Hands should be raised up alternately above the head when doing the } \\
\text { BSE in front of the mirror }\end{array}$ & 17 & 17 & 66 \\
\hline BSE should be done from the front view only & 40 & 28 & 32 \\
\hline BSE can be done in a supine position & 44 & 21 & 35 \\
\hline Palpate in the right breast while left-sided lying when doing the BSE & 18 & 26 & 56 \\
\hline U Use finger pulps to examine any lumps or thickening of the skin & 9 & 20 & 71 \\
\hline BSE can be done using the vertical strip and circular technique & 10 & 23 & 67 \\
\hline Need to press on the nipple to check any unusual discharge & 8 & 22 & 70 \\
\hline BSE includes arm-pit examination to check for any lump & 9 & 20 & 71 \\
\hline Need to observe any unusual change in the shape and size of breast & 12 & 19 & 69 \\
\hline Retraction of the nipple is a warning sign that should be observed & 6 & 23 & 71 \\
\hline Lump is the early sign for cancer & 15 & 27 & 58 \\
\hline
\end{tabular}

Table 6: Distribution of the participants by Knowledge Score

\begin{tabular}{|c|c|c|c|c|c|}
\hline Knowledge Score & Frequency & $\%$ & $\begin{array}{c}\text { Mean Knowledge } \\
\text { score }\end{array}$ & $\begin{array}{c}\text { Mean } \\
\text { percentage }\end{array}$ & Interpretation \\
\hline $\begin{array}{l}<24 \\
\text { unsatisfactory }\end{array}$ & 31 & $31 \%$ & 27.93 & 27.93 & satisfactory \\
\hline $\begin{array}{l}>24 \\
\text { Satisfactory }\end{array}$ & 69 & $69 \%$ & & & \\
\hline
\end{tabular}


Table 7: Distribution of the participants by BSE Attitude

\begin{tabular}{|c|c|c|c|c|c|c|c|c|}
\hline \multirow[t]{2}{*}{$\overline{\text { Attitude }}$} & \multicolumn{2}{|c|}{ Strongly dis agree } & \multicolumn{2}{|c|}{$\begin{array}{l}\text { Disagree } \\
\end{array}$} & \multicolumn{2}{|c|}{ Agree } & \multicolumn{2}{|c|}{ Strongly agree } \\
\hline & $\mathbf{0}$ & $\%$ & 1 & $\%$ & 2 & $\%$ & 3 & $\%$ \\
\hline Doing BSE makes me feel so funny & 36 & 36 & 18 & 18 & 22 & 22 & 24 & 24 \\
\hline BSE will be embarrassing to me & 16 & 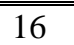 & 20 & 20 & 49 & 49 & 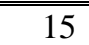 & 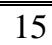 \\
\hline Doing BSE is wasting time & 23 & 23 & 34 & 34 & 36 & 36 & 7 & 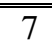 \\
\hline Doing BSE makes me feel unpleasant & 19 & 19 & 37 & 37 & 39 & 39 & 5 & 5 \\
\hline $\begin{array}{l}\text { If there is a lump, I prefer to get treatment } \\
\text { from a traditional healer }\end{array}$ & 14 & 14 & 15 & 15 & $\overline{252}$ & $\overline{252}$ & 19 & 19 \\
\hline $\begin{array}{l}\text { Feel uncomfortable, can't do BSE once in a } \\
\text { month }\end{array}$ & 35 & 35 & 24 & 24 & 21 & 21 & 20 & 20 \\
\hline All women should do BSE & 18 & 18 & 10 & 10 & 37 & 37 & 35 & 35 \\
\hline I really care about my breasts & 17 & 17 & 21 & 21 & 39 & 39 & 23 & 23 \\
\hline $\begin{array}{l}\text { I am not afraid to think about the breast } \\
\text { cancer }\end{array}$ & 22 & 22 & 26 & 26 & 31 & 31 & 21 & 21 \\
\hline $\begin{array}{l}\text { Avoid BSE because I worry about having } \\
\text { breast cancer }\end{array}$ & 21 & 21 & 16 & 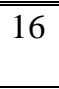 & 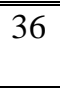 & 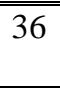 & 27 & 27 \\
\hline Interested in doing BSE & 35 & 35 & 21 & 21 & 29 & 29 & 15 & 15 \\
\hline $\begin{array}{l}\text { Always search for information regarding } \\
\text { BSE from the internet, magazines, and } \\
\text { newspaper }\end{array}$ & 22 & 22 & 18 & 18 & 44 & 44 & 16 & 16 \\
\hline Discuss with my friends about BSE & 16 & 16 & 22 & 22 & 47 & 47 & 15 & 15 \\
\hline
\end{tabular}

Table 9: Distribution of the participants by Attitude Score

\begin{tabular}{|c|c|c|c|c|c|}
\hline Attitude Score & Frequency & $\%$ & $\begin{array}{c}\text { Mean attitude } \\
\text { score }\end{array}$ & Mean percentage & Interpretation \\
\hline \begin{tabular}{|l}
$0-<20$ \\
Negative
\end{tabular} & 52 & $\overline{52}$ & \multirow[t]{2}{*}{19.72} & \multirow[t]{2}{*}{19.72} & \multirow[t]{2}{*}{$\overline{\text { Negative }}$} \\
\hline $\begin{array}{l}20-30 \\
\text { Positive }\end{array}$ & $\overline{48}$ & $\overline{48}$ & & & \\
\hline
\end{tabular}

Table 10: Distribution of the participants by BSE Practice

\begin{tabular}{|l||c|c||c||c|}
\hline \multicolumn{1}{|c||}{ Practice } & \multicolumn{2}{c||}{ Not done } & \multicolumn{2}{c|}{ Done } \\
\cline { 2 - 5 } & 0 & $\%$ & $\mathbf{1}$ & $\%$ \\
\hline \hline Do BSE once a month & 66 & 66 & 34 & 34 \\
\hline learning the correct method of BSE & 67 & 67 & 33 & 33 \\
\hline Parents or partner always advise to do BSE & 71 & 71 & 29 & 29 \\
\hline Advise friends to do BSE & 65 & 65 & 35 & 55 \\
\hline \hline Discuss the importance of BSE with friends & 63 & 63 & 37 & 37 \\
\hline Have been taught on BSE by health staff & 55 & 55 & 45 & 45 \\
\hline $\begin{array}{l}\text { If notice any breast abnormality, directly go to public } \\
\text { health care }\end{array}$ & 52 & 52 & 48 & 48 \\
\hline
\end{tabular}

Table 11: Distribution of the participants by Practice Score

\begin{tabular}{|c|c|c|c|c|c|}
\hline Practice Score & Frequency & $\%$ & $\begin{array}{c}\text { Mean } \\
\text { practice score }\end{array}$ & $\begin{array}{c}\text { Mean } \\
\text { percentage }\end{array}$ & Interpretation \\
\hline $\begin{array}{l}0-\quad<8 \\
\text { Bad practice }\end{array}$ & 100 & $100 \%$ & \multirow[b]{2}{*}{2.61} & \multirow[b]{2}{*}{2.61} & \multirow[t]{2}{*}{ Bad practice } \\
\hline $\begin{array}{l}8-14 \\
\text { Good practice }\end{array}$ & 0 & $\overline{0}$ & & & \\
\hline
\end{tabular}




\section{Discussion}

The present study was conducted to determine knowledge, attitude and practice among female nursing university students towards BSE. The age group most affected by $\mathrm{BC}$ in KSA and other developing countries is women younger than 50 years of age. ${ }^{[27]}$ The age of the participants ranged from 18 years to 25 years and the mean age was $21.9 \pm 2.7$ years. The study was appropriate in this age group as most of them were young adults who should be more enlightened on breast cancer and breast self-examination before they reach the age of common occurrence of the disease. This is congruent with the findings of ${ }^{[28]}$ which revealed that the majority were in the age group of $20-24$ years $(40.8 \%)$.Moreover, this result is in line with advice from health experts who indicated that women should begin breast examination as early as age twenty ${ }^{[29]}$. The result of the present study revealed that our participants had $69 \%$ satisfactory knowledge about BSE.

Early detection of breast cancer remains one of the key strategies for the control of breast cancer. Studies conducted in developing countries have established BSE as one of the most reasonable and feasible approach in early detection of breast cancer $^{[9]}$. BSE not only familiarize women with the appearance/feel of their breast but also aids in early detection of breast cancer ${ }^{[31]}$. Some of the studies have reported that BSE is highly effective in increasing sense of ownership about health, healthcare seeking behavior, encouraging adoption of preventive health behaviors and creating awareness about breast cancer among women $^{[33,34]}$. Multiple studies have concluded that women, who regularly perform breast selfexamination present with smaller neoplasm and rare involvement of axillary lymph nodes ${ }^{[31,32]}$. On the other hand, some researchers have seriously questioned the usefulness of $\mathrm{BSE}^{[12,13]}$, while others have revealed no added benefits of BSE in improvement of survival rates ${ }^{[35]}$.

The previous knowledge on BSE was high among our participants (98\%) this may be as a result of their nursing study.
Mass media was easily available and provide broad range of information, this explain our results that mass media represented the most common source of information for breast cancer among students. The result of the present study revealed that more than half of the study participants $(57 \%)$ have the source of information about breast cancer through mass media. Our study participants, reported barriers were dislike to touch, have no time, worry to find a lump $(23.3 \%, 23.3 \%, 20 \%)$ respectively. The results have, additionally, shown that "barriers" was one of the significant factors that affect women's decision to perform BSE.

In this study, breast feeding is one of the important protective factors from breast cancer. More than three quarters of the participants (84\%) reported that the breastfeeding prevents breast cancer.

In this study, regarding their knowledge on the frequency of $\mathrm{BSE},(37 \%)$ of the participants correctly reported that BSE should be done in every 2 months.. In this study, more than half of the participants $(56 \%)$ reported that BSE should be performed a week after menses. Overall knowledge score (69\%) regarding BSE for our study participants was satisfactory.

The attitude of the nursing students warrants addition of skills training and corrective feedback to improve the BSE proficiency.

Regarding practice of BSE more than half of the participants $(71 \%)$ revealed that parents are not advised them to do BSE. $67 \%$ of them not knowing the correct method of doing BSE. 66\% of the participants were not doing BSE once in a month. None of our participants had a good practice of BSE. This shows that provision of information is sufficient to obtain BSE initiation but not necessarily adequate to maintain the practice. Health education and communication have been found to promote health seeking behavioural change with sufficient utilization and compliance to breast cancer prevention and screening strategies. 
Most of the participants in this research have heard of BSE. Further investigation indicated that only $33 \%$ could correctly describe the procedure. Several studies on BSE have reported similar findings ${ }^{[33]}$. This may be as a result of poor health education in our society and also the perception that they cannot develop breast cancer. The health belief model (HBM) suggests that when a woman perceives herself at risk then she is more likely to practice $\mathrm{BSE}^{[34]}$

\section{Conclusion}

Though the knowledge on breast cancer and the BSE is high among the study population, the level of awareness of breast cancer and BSE is still very low leading to poor BSE performance

\section{Recommendation}

Based on the research conducted, it is recommended that there is a need to create awareness about the importance of BSE among female nursing students so as to improve the practice of it. We recommend that orientation program for fresh students should include talks on screening for breast cancer. Media activities should also be intensified to give reliable information about breast cancer and BSE. Proper education of the female students will have a positive impact on the society.

\section{Acknowledgement}

Grateful thanks to the students' who trust us and participate in this work and for the teaching staff at Faculty of Nursing, Northern border University for their valuable efforts and time. The authors acknowledge there was no external financial support for this study. We, also thank the anonymous reviewers for their constructive comments that helped strengthen the article.

\section{References}

1. WHO. (2013) Latest world cancer statistics Global cancer burden rises to 14.1 million new cases in 2012: Marked increase in breast cancers must be addressed In: IARC, editor. Lyon, France: International Agency for Research on Cancer.1-3.

2. Brown R, Kerr K, Haoudi A, Darzi A.( 2012)Tackling cancer burden in the Middle East: Qatar as an example. Lancet Oncol; 501-508.

3. Baron-Epel O, Friedman N, Lernau O. (2009) Reducing disparities in mammography-use in a multicultural population in Israel. Int J Equity Health; 819.

4. American Cancer Society. (2012).Cancer facts \&figures, USA.

5. Bray, F., Ren, J.S., Masuyer, E. and Ferlay, J, (2013) "Global estimates of cancer prevalence for 27 sites in the adult population in 2008," Int J Cancer 132 (5), 1133-1145,

6. Smith, R.A., Cokkinides, V., \& Eyre, H. J. (2006).American cancer society guidelines for the early detection of cancer. CA Cancer J. Clinic , 11-25.

7. Aderounmu, A.O., Egbewale, B. E., Ojofeitimi, E. O., Fadiora, S. O., Oguntola, A. S., Asekun- Olarinmoye, E. O., ... Akanbi, O. (2006). Knowledge, attitudes $\&$ practices of educated \& non-educated women to cancer of the breast in semiurban \& rural areas of South-West, Nigeria. Niger Postgrad med J, 182-188.

8. Dundar PE, Ozmen D, Ozturk B, Haspolat G, Akyildiz F, Coban S. (2006) The knowledge and attitudes of breast selfexamination and mammography in a group of women in a rural area in western Turkey. BMC cancer; 6-43.

9. Sreedharan J, Muttappallymyalil J, Venkatramana M, Thomas M. (2010) Breast Self-Examination: Knowledge and Practice among Nurses in United Arab Emirates. Asian Pacific J Cancer Prev. 651-654.

10. Tavafian SS, Hasani L, Aghamolaei T, Zare S, Gregory D (2009). Prediction of 
breast self-examination in a sample of Iranian women: an application of the Health Belief Model. BMC Women's Health; 1-7.

11. Avci IA (2008). Factors associated with breast self examination practices and beliefs in female workers at a Muslim community. Eur J OncolNurse;127-133.

12. Fung S. (1998) Factors associated with breast self-examination behaviour among Chinese women in Hong Kong. Patient Edu Counseling; 233-243.

13. Asnarulkhadi Abu Samah1, Maryam Ahmadian2 \& Latiffah A. Latiff2 (2016) Insufficient Knowledge of Breast Cancer Risk Factors Among Malaysian Female University Students. Global Journal of Health Science; Vol. 8, No. 1;

14. Deaton, J.G. (1988) How to Recognize Cancer before It's Too Late. Herald of Health, June, 9-11.

15. Abudu, E.K., Banjo, A.A.F., Izegbu, M.C., Agboola, A.O.J., Anunobl, C.C. and Musa, A. (2007) Malignant Breast Lesions at Olabisi Onabanjo University Teaching Hospital (OOUTH) Saganu: A Histopathological Review. Nigeria Postgraduate Medical Journal, 57-59.

16. Brunar, L.S. and Suddarth, D.S. (1988) Textbook of Medical Surgical Nursing. J. B. Lippincott Company, Philadelphia, 890895.

17. Peltzer, K., \& Pengpid, S. (2014) Awareness of Breast Cancer Risk among Female University Students from 24 Low, Middle Income and Emerging Economy Countries. Asian Pac J Cancer Prevention,. 75-78

18. Gwarzo U, Sabitu K, Idris S. (2009) Knowledge and practice of BSE among female undergraduate students of Ahmadu Bello University Zaria. North Western Nigeria. Annals of African Medicine.;5558.
19. Mohamed HA, El - Nagger NS and Sayed HY (2013).Knowledge, Attitudes and Practices Regarding Breast SelfExamination among Female Undergraduate Students in the Faculty of Applied Medical Sciences at Umm AlQura University. Journal of American Science 2013

20. Al-Haji KM and. Moawed (2015). Breast Cancer, Breast Self-Examination Knowledge among Female High School Students in Riyadh City. Middle east journal of nursing volume 9 issue 1 January.

21. Yakout1, S. M., Moursy, A. M., Moawad, S. and Salem, O.(2014) Awareness, Knowledge and Practice of Breast selfexamination among groups of Female nursing students, Riyadh, Kingdom of Saudi Arabia International Research Journal of Biological Sciences Vol. 3(2), 58-63

22. Mehrnoosh AZ, Muhamad HJ, Rosliza AM, irmi ZI, SALMIAH S. (2011) knowledge on breast cancer and practice of breast self-examination among selected female university students in Malaysia. Medical and Health Science Journal, MHSJ.; 7:49-56.

23. World Health Organization. (2014) Breast Cancer: Prevention and Control. WHO; Available from: http://www.who.int/cancer/ detection/breastcancer/en.[Last accessed on 2014 Nov 14].

24. Ferlay J, Bray F, Parkin DM, Pisani P. (2001) Cancer Incidence, Mortality and Prevalence Worldwide. IARC Cancer Base No. 5. [1.0]. Lyon, France: IARC;.

25. Yousuf S.(2010).Breast Cancer Awareness among Saudi Nursing Students. Med. Sci.; 17 (3): 67-78.

26. Molah Karim SA, Ali Ghalib HH, Mohammed SA, Fattah FH. (2015) The incidence, age at diagnosis of breast cancer 
in the Iraqi Kurdish population and comparison to some other countries of Middle-East and West. Int J Surg; 13: 7175.

27. Casmir, E.C.I., Anyalewechi, N.E., Onyeka, I.S.N., Agwu, A.C.O. and Regina, N.C. (2015) Knowledge and Practice of Breast Self-Examination among Female Undergraduates in South-Eastern Nigeria. Health, 7, 1134-1141.

28. Moustafa, D.G., Abd-Allah, E.S. Taha2, N.M. (2015): Effect of a Breast-Self Examination (BSE) Educational Intervention among Female University Students. American Journal of Nursing Science; 4(4): 159-165

29. Ahmad Ayed* Faeda Eqtait Lubna Harazneh Imad Fashafsheh Sewar Nazzal (2015). Breast Self-Examination in Terms of Knowledge, Attitude, and Practice among Nursing Students of Arab American University/ Jenin. Journal of Education and Practice. Vol.6, No.4.

30. Karayurt, O., Ozmen, D. and Çetinkaya, A.C, (2008) "Awareness of breast cancer risk factors and practice of breast selfexamination among high school students in Turkey," BMC Public Health, 8, 359,.

31. Gupta, S.K, (2009) "Impact of a health education intervention program regarding breast self-examination by women in a semi-urban area of Madhya pradesh, India," Asian Pac J Cancer Prev, 10 (6), 1113-1117,.

32. Austoker, J, 2003 "Breast selfexamination," BMJ, 326, 1-2.

33. Manasciewicz, R, 2003. "Breast selfexamination. Editorial misses central point," BMJ, 326, 710,
34. Nelson, H.D., Tyne, K., Naik, A., Bougatsos, C., Chan, B., Nygren, P. and Humphrey, L, 2013Screening for breast cancer: Systematic evidence review update for the US Preventive Services Task Force [Online]. Available: http://www.ncbi.nlm.nih.gov/pubmed/207 22173 [Accessed May 19].

35. Collaborative Group on Hormonal Factors in Breast Cancer. Menarche, menopause, and breast cancer risk: individual participant meta-analysis including 118,964 women with breast cancer from 117. epidemiological studies. Lancet oncol. 2012; 1141-51. 